\title{
Mothering Nations and Nationalizing Mothers: Reading the Fairytales of Colonial Bengal
}

SARANI ROY

\begin{abstract}
This paper argues how the fairytales of colonial Bengal resist closure in absorbing the very silence of the gendered discourse of nationalism of which the genre is a product. The paper tries to address how the nineteenth century Bengali fairytales registered subversive moments in the process of the evolution of a new historical consciousness, one that both accepted and rejected the dominant categories of available gender identities.
\end{abstract}

The paper broadly deals with issues of pregnancy and its representation in fairytales. It examines how particular sociocultural meanings of pregnancy play a vital role in the understanding of our fairy stories. The working definition of fairytale provided by Vladimir Propp insists that the functional axis of fairytale proceeds from lack toward fulfillment. While poverty has been the traditional marker of this lack in fairy tales from distant parts of the world, nineteenth-century Bengali fairytales have defined this lack especially in terms of childlessness. This is something symptomatic of the contemporary discourses of gender roles. This paper analyzes stories from collections like Thakumar Jhuli and folktales of Bengal involving discourses of pregnancy and childbirth, motherhood and fatherhood in ways varied and critical, and exposes the very instability of the cultural meanings of these concepts.

Keywords: Fairytales, gender, pregnancy, labour room, maleimpotency, breastfeeding, nationalism, colonial Bengal. 
Sarani Roy

\section{Introduction}

Recalling an early scene from Guillermo del Toro's Pan's Labyrinth, where Carmen, the very pregnant mother of the protagonist, Ofelia, feels a sudden need to vomit following her rebuke of Ofelia for carrying a book of fairytales, the question which has troubled me is whether the figure of the pregnant mother bears any special significance in the context of the film, especially in its use of the fairytale narrative not only as a thematic component but as a structuring principle. Whether the pregnancy narrative demarcates or delimits the generic scope of the fairytales is a question that I address in this paper. I look for the answers not in films from abroad but in the fairytales of colonial Bengal. The reference to the film, though brief and not pursued in detail, remains an important point of departure for my argument in this paper.

Shibaji Bandopadhyay in his seminal work on colonialism and children's literature in Bengal has observed how fairytales always move towards a definite telos but end by suggesting a timeless future: "so they lived happily ever after" (1991: 73). They show a consciousness of space but are apparently forgetful of time. Bengali fairytales have in fact spatialized time; crossing the seven seas and thirteen rivers are all that the prince takes in reaching the demon's den to retrieve the princess. But the complexities of dealing with time become unavoidable as soon as there is a pregnant woman present in the story. The span of her pregnancy is always specified in time; at times she is in a hurry to produce the newborn whose story it is going to be and at times the moment of delivery is unexpectedly prolonged to arrive at the climactic scene. In both cases there is an attempt to keep the pregnant body outside the main narrative discourse, in the process, however making it all the more central to the cultural meanings of the text. The pregnant body is essentially marked by porous 
boundaries and thereby it takes on unstable connotations vis-àvis the culture that produces it. The chief source of its fluidity is its ambivalent positioning in between visibility and invisibility. But it has always been the visible belly which has rendered the woman invisible. More recently, theorists have identified how the deployment of visual images of women's pregnancy not only alters their experience of being pregnant and their decision-taking capacity, but also alters the definition of maternity altogether (Maher 2002: 97).In Disembodying Women, Barbara Duden asks "How did the unborn turn into a billboard image and how did that isolated goblin get into limelight?" (1993: 37). The fact that the infant can be seen even before it exists in the world leads up to the erasure of the mother's subjectivity. It is a pre-formed person, "simply awaiting discovery" (Hartouni 1997: 23).

The working definition of fairytale provided by Vladimir Propp is relevant here. According to Propp, the functional axis of fairytale proceeds from lack towards fulfillment and the journey along this axis hinges on obtaining something precious from the other world followed by a return to the mundane world where the shift is necessitated by a stable string of thirty one "functions" (1986: 263). While poverty has been the traditional marker of this lack in fairy tales from distant parts of the world, nineteenth century Bengali fairytales have defined this lack especially in terms of childlessness. I shall be reading this as something symptomatic of the contemporary discourses of gender roles and their performances and shall also try to show how this reading can help us perceive something beyond the "universal", "timeless" status of fairytales. My reading would chiefly focus on four texts Thakumar Jhuli and Bongoponyasa Thakurdadar Jhuli by Dakshinaranjan Mitra Majumdar, The Folk Tales of Bengal by Lal Behari Day and the story of Kheerer Putul by 
Abanindranath Tagore. While the first three books are collections of fairytales supposedly collected from the firsthand accounts of the rural people of Eastern Bengal, Abanindranath Tagore's book is an original text written in the same generic mode as the other stories.

\section{The Issue of Language and Translation}

Apart from Day's text, all the other texts are written in Bengali. The earliest Day's book was written for a very specific and different kind of target readership apart from the other books. It was written with intention of familiarizing the English with Indian folk and fairytales. Apart from Thakumar Jhuli, I have not come across or used the translated version of any of the other texts even if there have been translations available. Even the translation of Thakumar Jhuli is a partial translation as it chooses only twelve stories out of the entire collection. So I have mainly used my own translations of texts wherever necessary. Perhaps it would be relevant here to briefly discuss the issue of language inherent in the fairytale collections we are dealing with. The very fact that the choice of language distinguishes Day's book from the other books despite being written in the same generic vein needs to be addressed. Writing in English and writing in the vernacular the same kinds of stories represented two very different political agendas. As in any other colonial transaction so does in standardizing the folklore research project language played a critical role. A derivative discourse and a colonial import the discourse of folklore had to grapple with the problematics of language. Born out of the rift between the oral and the written modes of language it finds itself trapped in an in-betweenness that can be molded to mean very different things. In every folklore-collection project, there remains a gap between the language of the folk whose lore is to be collected and the language of the collector/ethnographer/editor. The difference 
can be of dialects within the same language or of all languages. But certainly this difference is symptomatic of the asymmetry of power-relations between the two parties engaged in the act. It is needless to say that in a colonial situation the issue takes on more and new complexities. Initially collected and compiled in English, the language of the colonizer as in Day's collection, the Bengali folklore was gradually being co-opted by the vernacular, the language of resistance. Day tries to prove his efficiency in the task of collecting popular tales by saying that he was " (...) was no stranger to the Marchen of the Brothers Grimm, to the Norse Tales so admirably told by Dasent, to Arnason's Icelandic Stories translated by Powell, to the Highland Stories done into English by Campbell, and to the fairy stories collected by other writers (...)" (1912: 5). His familiarity with western works gives his own work, the preface of which he was writing, a kind of credibility and authenticity. This claim was important for someone who was struggling with the incompatibility that he believed existed between his Indian identity and the novel and elitist work he had undertaken. When vernacular came to be the medium of the collection of folk and fairy tales, the situation underwent a significant change. People like Dakshinaranjan Mitra Majumdar and Rabindranath Tagore countered Day's agenda of crediting and glorifying the British predecessors where they rejected any notion of comparison with the colonizer's texts and asked for an autonomous paradigm to discuss both written and oral texts of the East. However rejection of something is also to be conscious of its presence all the time. And that was the case with them. While Lal Behari Day acknowledged, whether knowingly or unknowingly, the contribution of written texts in shaping a new and different kind of orality in colonial Bengal, Mitra Majumdar and Tagore dismissed it completely to fit it into project of the anti-colonial nationalist identity construction. Without going into any more 
complexities but in keeping in mind the issues raised we would now try to read the texts in some details. What we shall see in the due course of the paper is how linguistic translation is only a prologue to the constant process of cultural translation in which these texts are engaged.

\section{The Discourse of the Labour Room}

Dakshinaranjan Mitra Majumdar in the preface to his Bongoponyasa Thakurdadar Jhuli has identified the labour room of rural Bengal as the birthplace of the numerous circuits of stories which have continued to enchant life there from time immemorial (1906: 14). Dakshinaranjan's preface merits special attention because of the way it makes connections between the labour room and fairytales. He even adds an annotation to further the discussion, elaborating how from the day the pregnant mother enters her labour room it becomes a community-practice to entertain her with an unending flow of stories; stories narrated, sung, performed till the middle of night. On the sixth day of the child's birth everyone remains awake till dawn for it is believed to be the night when the "bidhata purush", a word denoting someone like a divine messenger, will come down to write destiny on the infant's forehead (Mitra Majumdar 1906:14). The author of the preface has also added that in our traditional medical discourses of the Ayurveda, the practice has been considered especially beneficial to the expecting mother's health. Dakshinarajan's romanticization of the rural labour room actually falls into a larger project of the time - one that has set out to locate markers where cultural differences can be negotiated vis-à-vis the habits and customs of the colonizer. Partha Chatterjee, in one of his seminal texts, The Nation and its Fragments has elaborated a model in which he has shown how "[Indian] nationalism has separated the domain of culture into two spheres - the material and the spiritual" (1993: 119). While in 
the material sphere the claims of the western civilization reigned supreme in terms of science, technology, economic organization and statecraft, the spiritual sphere remained unparalleled in its superiority to the West (119-20). Elsewhere he has suggested this was necessary for the Indian nationalists because they had to draw the closure to the question of women in society, an issue hotly debated by both western thinkers and administrators and also by the Indian nationalist revivalists and reformists ("The Nationalist Resolution of the Women's Question" 1993: 237). While the British needed to highlight the "poor condition" of women in India to argue for the logical need of their "civilizing mission", the Indian nationalists had to reclaim their women "to protect, preserve and strengthen the inner core of the national culture, its spiritual essence" (239). All these arguments are important here for several reasons. Women's health and childbirth had been a constant focus in the "civilizing mission" of the colonizer who considered it "barbaric and medieval" to give birth at home with the help of midwives with no doctors, nurses or medicine. This, I argue, constitutes the moment of breach in the nationalist paradigm of thought which took pains to keep apart the western world of medicinal sciences and Indian women's health and problems of childbirth primarily because the two belonged to two different spheres of action - respectively, the material and the spiritual. The two cannot be equated despite the connections they may have. This is the process of selection which characterizes the appropriation of colonial modernity. Dakshinaranjan's representation surely has a political claim to make because we are to remember the tryst between Tagore and Dakshinaranjan in "collecting" the tales of Bengal in Thakumar Jhuli as a desperate attempt in replicating "the musical aura of the past" in "the present-day idiom of Bengali language" (Tagore 2012: xii). In writing the Preface to the book, Tagore asks rhetorically "Can there be anything more 
quintessentially indigenous [my emphasis] than Thakumar Jhuli in our country?"(xi).This project of nation-building had its own silences and aporias which need to be discussed and for that we will have to go back to our fairytales once more.

The representation of the labor room complicates the fairytales to a greater extent. The Bengali word for labour room is antur ghor and as the Bengali dictionary tells us it denotes a separate place exclusively set for the pregnant mother till the birth of the child (Basu 1937: 570). It is quite different from the western labour room that is precisely a medicalized space meant for the delivery of the child while the antur ghor is retained for a broader span of time. The western model of the labor room is located within the hospital which is a male domain as opposed to the antur ghor which is primarily a female space. The antur ghor is a suspension of the marital bed when the woman is carrying her child. In post-pregnancy period, the antur ghor takes on a different function. It sanctions the female body's return to normalcy by institutionalizing the suspended menstrual cycle followed by a dip into the Ganges after twenty one days. Altogether the antur ghor experience provides the new mother with rigorous social training upholding values like restraint, sacrifice and thereby reinforcing the conventional meanings of motherhood. More importantly, this is also a period when the woman is subject to constant vigilance and the policing are done by the other women of her family and neighborhood. And exactly this is where our fairytales would lead us to while exposing the invisible links between the discourses of patriarchy and nationalism. The stories of "Kironmala," "Princess Kolaboti," and "The Champa Brothers" from Thakumar Jhuli hinge upon the dangerous potential of the labour room as an exclusively female space functioning outside the male supervision. Due to its veiled status it involves an ambivalent positioning between 
Mothering Nations and Nationalizing Mothers:...

power and powerlessness. The supposedly vulnerable condition of the pregnant woman inside it grants a position of control and authority to the other women who are in charge of her. All of the three above-mentioned stories are marked by the disappearance of the new-born child immediately after the birth. The other women deputed to take care of the pregnant mother are responsible for this as they are clearly jealous of the new privilege accorded to the expecting mother. They declare the child to be dead as a consequence of which the new mother falls a victim to the king's wrath and is rendered homeless. In "Kironmala" it is the spinster aunts and in "Champa Brothers" it is the other queens who are the evil players. "Princess Kolaboti" is a slight variation of the theme where the youngest queen only gets to drink the leftovers of the other queens who have finished taking the magical herb prescribed to induce pregnancy. As a result the youngest queen gives birth to a monkey and subsequently is banished from the palace by the king. To talk about Abanindranath Tagore's Kheerer Putul or The Condensed Milk Doll we have to think whether it can be put into the same brackets with the other fairytales as it is certainly not part of any "collection" and is an original text. However there can be no doubt that it uses the dominant model of Bengali fairytales and also consciously plays with its conventions. In Kheerer Putul the labour room is an absence for the child who is never born. Yet the elder queen enjoys all the privileges of a pregnant woman including new house, good food, maids to look after and so on. The fact that the king cannot see his son for ten years until the day when the son gets married prolongs the period of the queen's supposed pregnancy. And it is again a female intervention that threatens it. The witch on recommendation of the jealous younger queen sells her poisonous sweets. What we are looking at here is actually the transition when the personal becomes the political. The nineteenth century was a turbulent time in the history of 
Bengal when all the distinctions between the categories of the public and the private were miserably blurred. The decisions taken within the four walls of female quarters had the potential to change the course of the history of the nation and the female body was the site where the questions of nationalist selffashioning could be negotiated. The labour room was private in its location but public in its function, a mediating space between the palace and the outside world - a life of privilege and a life of struggle. Once expelled from the labour room, the mother and child together bring into focus the internal divisions that characterize the king's kingdom. While the unfortunate children grow up fast and try to mend the ways of the world, the destitute mothers literally become working-class figures: the rag picker in "Champa Brother," the maid servant in "Princess Kolaboti," and so on. We may remember the monkey in Kheerer Putul. A representative of the common masses, visibly the "other", he is instrumental in restoring equilibrium in the country. The return of the lost child then becomes a symbol of a possible reintegration of the nation. Until then the labour room remains a mystery. This is actually the mystery of origins to which the tale has to return. The entire point of a fairytale is to draw a "suitable," "happy" closure to the narrative of origin - not only the origin of an individual but the origin of a nation.

\section{Structuring the Monogamous Family}

Why the discussion of pregnancy becomes imperative to understand the cultural contradictions of the time is quite clear. The pregnant women epitomize a change in the existing order, a possible beginning of a new order as well as an end to the existing order. The pregnant body is perhaps the most suitable metaphor of a time in transition. The women of our fairytales are impregnated by polygamous kings, men who fall easy victims to the traps of the 'other' women; but there is a marked 
difference between the characters of the fathers and the sons that are born in the due course of the stories. What distinguishes the male children from their fathers is the practice of monogamy, the most important tool of furthering the bourgeois notion of the perfect family and by extension imagining the perfect nation. Thus the fairytales shrewdly juxtapose feeble, foolish, incompetent fathers who owe their weaknesses to their questionable and polygamous characters with their equally mature, intelligent, responsible and invariable morally upright, monogamous sons. This is surely not an isolated case; nor is it coincidental. Tracing similar tendencies in the representation of love and marriage in the nineteenth century genre of the qissa, Kumkum Sangari points out, "There is a structural shift from the noble hero's acquisition of women and wives to the institution of monogamy, as well as a shift of narrative interest to female protagonists in which, paradoxically, misogyny provides the structural coherence" (2004: 217). The treatment of love changes drastically in these genres from its treatment in traditional romances. The main thrust of the idea of love becomes the relocation of "male desire in marriage by making it the (only legitimate) space of sexual pleasure and instituting the exclusivity of the wife's claim" (227). "In premodern romances and devotional traditions, love was often associated with transgression or rebellion but could still occupy, in common with prescriptive traditions, emotional structures that were monogamous, enduring or monogamous for women, polygamous, transient or sequential for men. However, in emerging nineteenth-century definitions, love marriage was associated with monogamy for women and men. It privileged the choice of partner and promised an end to male promiscuity" (227-8). Now it's "an unrebellious, politically and socially ratified love that could double as a pragmatic rapprochement with bourgeois notions of conjugality" (228). 
Here the fairytale, like the qissa, in redefining the interrelations of love and marriage, "intersects with many of the key themes in nineteenth-century reformism: the reconciliation of duty and desire for men and proper institutionalization of monogamous marriage were part of the problemtic of patriarchal sexual regulation. Male decadence (...) was a recurring concern and one item on the agenda was to wean them from the company of the prostitutes and low castes (...) the emphasis falls on so much as on reforming repositioning male desire and vanquishing the 'other' woman. It resolves the decline and fall of the landed aristocracy through a salvage narrative that proposes to domesticate male sexuality. It tames the older masculinity, identifies royal authority with sexually regulated masculinity (...)" (227-8). Advocacy for monogamy and locating love and sexual desire within marriage was done on the pretext of producing "better progeny and end family conflicts; it even praised the ancient the practice of swayamvara, a princess choosing her husband in public assembly for having ensured mutual attraction and compatibility" (228). But the transition from one order to the other is never easy; it certainly has its moments of clashes and overlapping. Nineteenth century Bengali fairytales are caught somewhere in between the old and the new orders, between polygamous kings and monogamous princes, between the reality of the broken families and the dream of the companionate marriages, between the residual and the emergent. The pregnant mothers though deliver their children, but cannot resolve the conflicting meanings of motherhood. Thus Duo Rani in Kheerer Putul is pregnant even without a child in her womb. Loving and caring for a monkey is enough to satisfy her motherly instincts, yet the story cannot end until she produces a male heir to the kingdom; and though the evil Suo Rani, the other woman is strategically removed there remains much doubt and uncertainty about the possibility of 
restoration of mutual love and respect between the king and the Duo rani. On the other hand the daughters who are born out of this pregnancy who do not have such 'great' responsibilities on their shoulders as protecting the family-line or the country oscillate between various roles, are surely given less importance in comparison to their male counterparts. Yet they stand out as exceptionally gifted individual at times outshining their brothers in merit and efficiency like Kironmala or Champa perhaps because they are the future mothers who will have to produce national heroes.

\section{Childlessness, Male Impotency and the "Wish to be Female"}

The idea of male impotency is somewhat unique to these tales where the shame of being childless is assigned to the king instead of the more common practice of accusing and excommunicating the woman. The stories of "Madhumala", "Pushpamala", "Malanchamala", from Bongoponyasa Thakurdadar Jhuli open with the king's mourning for a child. It is curious the way he is called "antkunde", the Bengali word for impotent where the gender is identified as masculine (Basu 1937: 48) in "Madhumala" and is shown to be living a life of humiliation and depravity for not being able to produce an heir where even the sweeper has the audacity to dismiss the king for being impotent. Does this signify an improved status of women in society? To locate this shift, I have looked into the correspondences between Freud and his Indian psychoanalyst friend Girindrasekhar Bose. Bose, noticing the absence of castration fears in many of his patients (most of them were middle-class, educated Bengali bhadralok of nineteenth century Calcutta), a symptom claimed to be universal in men by Freud, reported it to the latter (Indian Psychoanalytic Society 1964: 16-17). Bose has defined this absence as a "wish to be female" which was prevalent in Bengali men (17). 
Christine Hartnack's postcolonial reading of the situation demands special attention here. According to her these men indeed wished to be female for they envied their own women who lived an unchanged life in the safety of the home, unaffected by the realities of colonial domination while they had to remain stuck to the colonial chronotope of the merchant offices (2003: 10). Following this line of argument, Hartnack interprets the wish "as a desire not to be tainted by colonialism, to belong to a world imagined to be all Bengali, thus untouched by the stresses and conflicts induced by foreign rulers, or as an imaginary withdrawal into a presumably ahistorical pre-colonial time, where the contemporary demands for change were not an issue" (2001: 147). In "Pushpamala," impotency is even represented as an equalizing force which makes the king no less a subject of pity than his executioner who is also childless. Even to highlight the absolute powerlessness of the king it is ultimately the executioner who is awarded a son and the king finds himself bound in an unwanted pledge of marrying his daughter to the executioner's son. The sense of being powerless to change anything of the colonial reality remained omnipresent in the male consciousness which perhaps found its displaced expression in their experience of being impotent and childless in the fairytales of this time.

\section{The Representation of the Issue of Breastfeeding}

The story which deals with the idea of pregnancy and its corollary issue of breastfeeding is "Shankhamala" from Thakurdadar Jhuli. "Shankhamala" settles the dispute of "the real" mother by a unique test in which the two mothers are asked to make a public display of their ability to breastfeed. As a result the real mother turned out to be the one whose milk went straight into mouth of the boy without faltering a little as opposed to the false one whose milk could cover only a short 
distance coming out of her breast. The episode is significant in showing how the female body is discursively constructed where it is literalized that a woman's body and her reproductive abilities indeed constitute her social position. We must here refer to Rousseau who talked at length on the debate between the efficacies of breastfeeding and wet nursing in the context of late eighteenth and early nineteenth century Europe. In Rousseau's argument wet nursing represented a complete moral travesty in need for reform which he saw as symptomatic of a society in political and social decay (1979: 45-46). Penny Weiss and Anne Harper point out that Rousseau's criticisms of wet nursing were not to do with the quality of a mother's care but rather with the dangers it presented to blood ties and patriarchal patterns of family (2002: 52). To save a declining moral order Rousseau even put women on public display, and what they displayed was a capacity for "perfected pity," "the possibility of free-imagining bodily needs and compulsions as ethical, and putting the impulse of commiseration to the service of the social order" (Wingrove 2000: 34). They created "a maternal spectacle," (159), as a defense against the civilizational contamination of what is "naturally" good and "naturally" feminine. In turning motherhood into festivity, Rousseau invoked the dangers inherent in coalescing the categories of the private and the public, the personal and the political. We cannot forget that even a touching spectacle was still a spectacle, and virtuous display was still a display. The ending of "Shankhamala" features a similar spectacle which serves the function of restoring the real mother to her glory, that of punishing the false mother and sustaining the family and the kingdom. It answers all the questions of the legitimacy of Shankha's pregnancy in the absence of her husband, guaranteeing her chastity. 
In juxtaposing the two mother-figures the story directly draws on the contemporary discourses and debates around the comparisons between the European and Indian mothers, and their respective breast-feeding and child-rearing techniques. The body of the mother with a special focus on her breasts was attributed with serious political connotations which quickly became the site where important resolutions to the imperialist as well as nationalist questions could be drawn. The issue of racial purity and superiority came up with great prominence. The purity of the mother's milk was to play a deciding role in securing the purity of the (male) child's blood. This was also the time which witnessed a remarkable growth in the medicalization of maternal health and the post-natal phase. Contemporary colonial health manuals talked about the problem of the scarcity of lactation of the memsahibs whose bodies could not cope with the tropical climate of India and consequently they had to hire native Indian wet nurses to feed their children. The white fraternity of India did not really approve of this practice as the bodily 'touch' of the lower-class Indian woman threatened to 'contaminate' the European child (Saha 2017: 149-51). In contrast to the 'dry' bodies of the English memsahibs the heavily lactating bodies of the Indian women were seen as a source of excess, and fecundity and therefore a site of questionable moral behavior which also made the possibility of the white man's sexual attraction to these women a constant point of anxiety. On the other hand, in the anti-colonial Indian nation-building project the phenomenon of wet nursing English children by Indian women was seen in two ways; one showed an apparent sense of dismay born out of the feeling that it is by depriving the Indian children that these women were feeding the masters' children thereby weakening the whole racial-national fight against the colonizer; the other way involved a more subtle sense of racial superiority which was a result of the glorification of the act of 
breast-feeding itself. What was suggested was that Indian women were morally far more superior to their western counterparts precisely because they were greater mothers who could better sacrifice for the welfare of their children. Among the European nobilities hiring wet nurses was already quite popular even in their own countries which also become clear from our reference to Rousseau. Even when there was no climatic or biological reason responsible for the lack of production of milk, the European women chose not to breast feed being driven by ideas like bodily fitness and fashion consciousness. It is interesting how the public realm of science and the private realm of women's child birth converged in the woman's body in nineteen century Bengal making it the 'contact zone' where two conflicting cultures encountered each other; also it became instrumental in defining a new nationhood grappling between tradition and modernity. So the apparently simple question 'who is the real (or the better) mother' that the fairytale in Day's collection deals with, takes on very loaded dimensions when read in the context of the time of its (re)production.

Speaking of pregnancy we cannot help thinking in terms of hunger, desire and excess - ideas related to female biology with which the patriarchal society has been traditionally uncomfortable. The female body lactates to regulate its excess. Self-preservation and self-gratification are the carnal points of the narrative of pregnancy no matter how much patriarchy denies those. In "The Boy whom Seven Mothers Suckled" from Lal Behari Day's The Folktales of Bengal, the elder six queens eat up their own newborn babies out of severe hunger. The only exception is the youngest queen who decides to keep her son alive and all the six queens help in nursing him; they all suckle him; the child is born to not one but seven mothers. The story is central to this discussion for it registers the 
lacunae of the dominant discourses of pregnancy and motherhood that operate primarily by glorifying the sacrificial and ever-suffering image of the mother. It hints at the central contradiction inherent in the discourse of motherhood that of between the woman's individual, autonomous existence and her overarching motherly persona upon which the culture projects most of its expectations. The story of "Malancamala" strikes an even more rebellious note in rendering the connections between motherhood and sexuality clear and obvious. Married to a new born child Malanca feeds her own husband. The boy takes full control of his wife's breasts and since there is no father to confront he grows up without knowing the oedipal wish. She is an interesting variant of the wet nurse figure who shows the limitations of simple biological motherhood and represents the deeper possibilities of the relationship with the foster-child which not being sanctioned by blood-ties, at times even makes room for a dangerously unsettling, incestuous liaison.

\section{Conclusion}

In the course of our discussion we have seen that the fairytales of colonial Bengal were structured around the two choices of motherhood- that of the good and the bad mothers, mothers adequate for reproducing eligible national heroes and mothers intent upon destroying the potential in the possible future heroes. The struggle is that of between the Lakkhi and the Putana. Lakkhi, often preceded by the Maa address, the Hindu goddess of wealth and prosperity, is also the embodiment of the ideal wife and the mother. Lakkhi is often contrasted with Putana, "the Hindu mythological demoness responsible for infants' diseases and infanticides"; contemporary medical practitioner Sundarimohan Das referred frequently to Putana "as a metaphor to criticise mothers who refused to breastfed their babies or caused infanticide by irregular breastfeeding 
without proper care" in his paper titled "Ravages of Putana" (Saha 2017: 155-57). On the other hand the new Hinduised as well as medicalized nationalist idealization of Indian motherhood found its expression in the mythologized figure of Lakkhi who was both educated in the modern scientific ways of child-care and who had also naturalized breastfeeding as the most desirable and necessary act to accomplish motherhood (155). What I argue here is Shashthi, another mythological deity though not classical or pan-Indian as Lakkhi, emerges as a balance between these two extreme forms of motherhood. The entire question of the struggle between the reified image of the mother-goddess and the "real" woman of flesh and blood claiming to live in her own right is dealt by Abanindranath Tagore in Kheerer Putul where goddess Shashthi is unable to control her lust for the condensed milk doll. Even being a "goddess" her human needs are still alive. The sacrificial aspect of motherhood is subtly undermined by the appearance of Shashthi who ate up the condensed milk doll in the same way as the six mothers gobbled up their sons in Lal Behari Day's story, yet her benevolent intervention ensures the happy ending to the story. When the text equates and replaces the doll with a real (male) child the larger political project becomes clear as it not only completes the fragmented royal family but also secures the future of the country. Yet many questions remain unresolved in the text including the death of the childless, villainous Suo Rani and the status of the newborn child who occupies the in between space of the natural and the foster child and also the disturbing suggestion that the smart monkey is likely to outshine the new-born prince in all capacities in near future. But the point remains that Shashthi, a Hindu folk goddess, venerated as the benefactor and protector of children, especially as the giver of male child, takes on an alternative independent female identity in the text. Perhaps what we are seeing is the woman coming into age, growing 
increasingly conscious of her body, emerging out of the Bengal Renaissance with too much force to be safely enshrined within the perfect private sphere which colonial modernity has designed for her. This is the threshold moment in the formation of a new historical consciousness where the long-held beliefs of a culture are contested. The time demanded contradictions. Thus the fairytales had to end without proclaiming a closure.

\section{Note}

The present article was published as part of the conference proceedings of the $15^{\text {th }}$ International Conference organized by MELOW (The Society for the Study of the Multi-ethnic Literatures of the World) and MELUS-INDIA (The Society for the Study of the Multi-ethnic Literature of the US-the India Chapter) held in Guru Govind Singh Indraprastha University, Dwaraka, New Delhi from 19-21 Feb, 2016.

\section{References}

BANDOPADHYAY, SIBAJI. 1991. Desher Roopkotha O Roopkothar Desh. Gopal Rakhal Dwandwa Samas. Kolkata: Karigor. 65-98.

BASU, RAJSHEKHAR. 1937. Chalantika: Adhunik Bango Bhashar Abhidhan. (comp.). Calcutta: M. C. Sircar.

ChAtTERJEe, PARTHA. 1993. The Nation and Its Fragments. New Delhi: Oxford University Press.

Chatterjee, Partha. 1993. The Nationalist Resolution of the Women Question. In Kukum Sanghari and Suresh Vaid (eds.), Recasting Women: Kali for Women, 233-53. New Delhi: Oxford University Press.

DuDEN, BARABARA. 1993. Disembodying Women:

Perspectives on Pregnancy and the Unborn. Cambridge: Harvard University Press.

Day, ReV. Lal BeHARI. 1912. Folk Tales of Bengal. London: Macmillan and Co. 
Mothering Nations and Nationalizing Mothers:...

Hartnack, Christine. 2001. The Uses of Psychoanalysis in the Treatment of Indian Patients. Psychoanalysis in Colonial India. New Delhi: Oxford University Press. 12062.

HARTNACK, Christine. 2003. Freud on Garuda's Wings: Psychoanalysis in Colonial India. IIAS News Letter 30. Online:https://iias.asia/sites/default/files/IIAS_NL30_10.p df.

Hartouni, VAlerie. 1997. Cultural Conceptions: On Reproductive Technologies and the Remaking of Life. Minneapolis: Minnesota University Press.

INDIAN PSYCHOANALYTIC SOCIETY. 1964. The Beginnings of Psychoanalysis in India: Bose Freud Correspondence. Calcutta: Indian Psychoanalytic Society. Online: http://cscs.res.in/dataarchive/textfiles/textfile.2008-0730.2177021617/file.

MAHER, JANE MAREe. 2002. Visibly Pregnant: Toward a Placental Body. Feminist Review 72. 95-107.

Mitra MAJUMDAR, DAKSHINARANJAN. 1906. Bangoponyasa

Thakurdadar Jhuli. Kolkata: Mitra and Ghosh.

Mitra MAJUMDAR, DAKSHINARANJAN. 2012. Tales from

Thakumar Jhuli: Twelve Stories from Bengal, trans. by

Sukhendu Roy. New Delhi: Oxford University Press.

PROPP, VLADIMIR JAKOVLEVIC. 1986. Morphology of Folktale.

Translated by Laurence Scot and edited by Louis A.

Wagner. Austin: University of Texas Press.

Rousseau, JEAN-JACQUeS. 1979. Emile. Harmondsworth: Penguin.

SAHA, RANJANA. 2017. Milk, 'Race' and Nation: Medical Advice on Breastfeeding in Colonial Bengal. South Asia Research 37. 147-65.

SANGARI, KumKum. 2004. Multiple Temporalities, Unsettled Boundaries, Trickster Women: Reading a Nineteenth Century Qissa. In Stuart Blackburn and Vasudha Dalmia 
Sarani Roy

(eds.), India's Literary Traditions: Essays on the Nineteenth Century, 213-50. New Delhi: Permanent Black.

TAgORE, ABAnindranath. 1896. Kheer er Putul. Kolkata: Signet Press.

TAGORE, RABINDRANATH. 2012. Tales from Thakumar Jhuli:

Twelve Stories from Bengal by Dakshinaranjan Mitra Majumdar, xi-xiii. New Delhi: OUP.

Toro, GuILERMo Del, DIR. 2006. Pan's Labyrinth [El Labertino del Fauno]. Picture House -Telecinco-Estudios Picasso Tequila Gang Esperanto Filmo.

WeISS, PENNy and ANNE HARPER. 2002. Rousseu's Political Defense of the Sex-Roled family. In Lynda Lange (ed.), Feminist Interpretations of Jean Jacques Rousseau, 42-64. State College: Pennsylvania State University Press.

Wingrove, Elizabeth. 2000. Rousseau's Republican Romance. Princeton NJ: Princeton University Press. 